\title{
Connotation of Socialist Legal Culture with Chinese Characteristics
}

\author{
Ximei Zhang \\ Chifeng University \\ Chifeng, China 024000
}

\begin{abstract}
To correctly understand the "rule of law" culture, we must understand it in comparison with the "rule of man" culture, and we must also understand the structural elements and functions of the "rule of law" culture. The socialist legal culture with Chinese characteristics has its fundamental premise: socialism with Chinese characteristics; its fundamental purpose: "people-oriented"; its guiding philosophy: governing the country according to law, making law enforcement for the people, following fairness and justice, serving the overall situation, following leadership of the party; and the connection with local culture: both being rooted in the mother culture and achieving transformation and transcendence; the relationship with the achievements of world civilization: the indispensable important resources in the cultivation and formation of socialist legal culture with Chinese characteristics.
\end{abstract}

Keywords-socialism with Chinese characteristics; rule of law; "rule of law" culture

\section{INTRODUCTION}

At the celebration of the 95th anniversary of the founding of the Communist Party of China, General Secretary Xi Jinping first proposed "Four Confidence." It is clearly emphasized that "the whole party must strengthen the confidence of direction, confidence of theory, confidence of system, and confidence of culture".[1] At present, "Four Confidence" is the latest achievement in understanding of the theory of socialism with Chinese characteristics. The socialist legal culture with Chinese characteristics is an important part of socialist cultural construction. To maintain confidence of culture, we must strengthen the construction of "rule of law" culture. At the same time, to build a socialist country under the rule of law with Chinese characteristics, we should take the construction of the "rule of law" culture as the foundation. To build a socialist legal culture with Chinese characteristics, we must first have a clear understanding of this concept.

\section{ThE "Rule OF LAW" CUlture}

\section{A. The Meaning of the Rule of Law Culture}

In a broad sense, the "rule of law" culture is represented as the concept of the rule of law, specification of the rule of law, behaviors of the rule of law, and the carrier of the rule of law with the idea of the "rule of law" and the spirit of the "rule of law" as the core; and in a narrow sense, the "rule of law" culture refers only to the idea of the "rule of law" culture, which is the soil and foundation for construction of the rule of law, providing intellectual support for construction of the rule of law and reflecting the degree of legalization in state governance. The "rule of law" culture discussed in this article refers to the rule of law culture in a narrow sense. To correctly understand the "rule of law" culture, we must pay attention to the following points: (1) The "rule of law" culture is a concept with holistic and epistemic meanings, rather than a partial and secondary concept. (2) The "rule of law" culture is a concept with distinctive value orientation and value judgment. It inherently implies a value orientation, that is, only the ideological factors that promote the production and implementation of "good laws" are the "rule of law" culture, and "the rule of evil law" is not an integral part of the "rule of law" culture. It is a progressive culture that stands in opposition to the "rule of people" culture. (3) In the comparison of the two concepts of the "rule of law" culture and the law culture, for the purpose of proposing the "rule of law" concept, we are no longer satisfied with the study of the construction of explicit legal culture such as laws and regulations, we should treat with the rule of law in the dynamic development of construction of the "rule of law" from its establishment, implementation to realization, and pay more attention to the construction of implicit legal culture at the level of the spirit of the rule of law and the behaviors of the rule of law, so that we can provide more lasting spiritual motivation, cultural heritage, and intellectual support for the construction of the rule of law, and build the advanced legal culture to lead the construction of China's rule of law in a new era as soon as possible.

\section{B. The Structural Elements of the Legal Culture}

Some scholars believe that "the legal culture should include human excellent law culture types such as values of democracy, human rights, equality, freedom, justice, fairness, etc.", Professor Liu Bin believes that "the research areas of the legal culture mainly include culture of legal concept, culture of legal system, culture of legal organization, culture of legal facilities (materials), culture of legal behavior, culture of legal language and text, totaling six aspects." ${ }^{3}$ Professor Liu Guiming, editor-in-chief of "Democracy and Legal System", proposed that we need to consider the issue whether "people is dominated" or the law is dominated, and whether the law is dominated or the government is dominated. The legal culture is to establish a "law-dominated" culture. He defined the outline of the legal culture: first, the culture of procedure. 
Stress on procedures, rather than the traditional "one word decides all"; second, the culture of rules. For example, it is not guilty when the law does not specify for it; third, the spirit of contract. Culture of contract is a kind of combination culture, which contains tolerance, and it is a compatible culture. ${ }^{4}$

Culture is a broad and rich concept, and cultural structures can also have many different divisions, such as surface structure and deep structure, material layer (material culture), spirit-material combination layer (system culture) and psychological layer (spiritual culture). The contemporary American cultural anthropologist Crookhong in his cultural structure theory believed that culture contains tangible culture and intangible culture, of which tangible culture is delomorphic, and intangible culture is invisible. ${ }^{5}$ Referring to the theory of cultural structure, the author believes that the structure of the legal culture content covers the four levels of "spiritual consciousness", "regulatory system", "behavior mode", and "substance carrier" of the rule of law in the broad sense, and it emphasizes the leading and core level of "spiritual consciousness" in the narrow sense. The legal culture is discussed in this task mainly starts from a narrow sense. From a narrow sense, the culture of rule of law mainly includes the legal mentality, the legal emotion, the legal awareness, the legal concept, the legal spirit, the law value, the legal idea, the legal principle, the legal thinking, the legal ideology, the legal theory, and the belief in the rule of law that condense and embody the requirements of the rule of law.

\section{The Main Functions of the Legal Culture}

The legal culture has important social and cultural functions, mainly as follows: (1) Demonstration function. That is, it makes a convincing argumentation and explanation on the legitimacy, reality, regularity, and practical operation of the rule of law. (2) Integration function. That is, through the spread of the legal culture and infiltration among the members of the society, it integrates the pluralistic society into an organic community that has a common concept and law value of the rule of law and makes operation under a unified order of the rule of law. (3) Gathering and shaping function. That is, following the common values and the rules of conduct provided by a certain legal culture (such as the rule-of- law culture of government, the legal culture of judicature, the ruleof-law culture of campus, the legal culture of enterprise, etc.), it makes a certain range of group members gather and shape their proper quality in a good order. (4) Guidance function. That is, it makes an integral guidance for individuals from spiritual consciousness and values to behavioral norms and behavioral habits, and urges them to completely shape their legal qualities that meet the social requirements of the rule of law in the new era. (5) Makeup function. That is, based on the legal culture and the advantages of coverage, it makes a timely and effective makeup and supplement for existing defects and insufficiency of the legal system. (6) Radiation function. That is, the high-quality legal culture in the advanced areas under the rule of law will inevitably generate significant radiation and lead effects in areas outside of it; at the same time, the advanced and high-quality legal culture will also produce an obvious infiltration and impact on the cultural phenomena in other fields such as political culture, economic culture, and moral culture.

\section{Socialist LEGAL CUlTURE With CHINESE CHARACTERISTICS}

The socialist legal culture with Chinese characteristics not only has the common attributes of human legal culture, but also has the personality characteristics based on China's national conditions.

\section{A. The Basic Premise: Socialism with Chinese Characteristics}

In the relationship with the socialism with Chinese characteristics, the socialist legal culture with Chinese characteristics should be based on the four-in-one socialist path with Chinese characteristics, the theoretical system of socialism with Chinese characteristics, the socialism system with Chinese characteristics, and the socialist culture with Chinese characteristics. As the four major substantive contents to support the socialism with Chinese characteristics, the socialist path with Chinese characteristics, the theoretical system of socialism with Chinese characteristics, the socialism system with Chinese characteristics, and the culture of socialism with Chinese characteristics are respectively the way to realize the socialism with Chinese characteristics, the guide to action, the fundamental guarantee and the spiritual strength. This is the most important achievement that the Chinese nation has made through hardships. It is the foundation of national prosperity and rejuvenation and is the cornerstone of China's development. They provided a fundamental political prerequisite for all socialist undertakings including the socialist legal culture with Chinese characteristics, and opened up a broad space for development. Therefore, the socialist legal culture with Chinese characteristics must take this as the basic premise, not deviate from it.

\section{B. The Fundamental Purpose: "People-oriented"}

For the socialist legal culture with Chinese characteristics, we should consciously implement the "people-oriented" principle and always follow the basic tenet of respecting people's principal status, protecting people's rights and improving people's quality. People are not only the creators and communicators of culture, but also the recipients and carriers of culture. In this sense, people are both the subject of culture and the object of culture. Therefore, it is more appropriate to regard "people-oriented" idea as an important concept of cultural development and cultural undertakings. Specifically, the "people-oriented" idea as the fundamental purpose of the socialist legal culture with Chinese characteristics should mainly be reflected in the following aspects: First, we must ensure that people's dominant position in the country and social life, and fully respect and give play to the people's creative spirit and principal wisdom in the construction of socialist legal culture; second, we should support and realize good laws and good governance with an excellent legal culture, and effectively guarantee the realization of citizens' legal rights; third, we should lead with an outstanding legal culture and pay attention to cultivation 
and promotion of law quality of all citizens, and then fully improve the cultural quality of citizens.

\section{Guiding Principles: Ruling the Country according to Law Enforcing the Law for the People, Making Fairness and Justice, Serving the Overall Situation, Following the Party's Leadership}

From the guiding principles, the socialist legal culture with Chinese characteristics should be based on the guiding philosophy of "ruling the country according to law, enforcing the law for the people, making fairness and justice, serving the overall situation, and following the party's leadership". Philosophy is the essence of ideology and theory, and is the essence of guiding practice. In 2006, the Party Central Committee put forward the socialist legal concept of "ruling the country according to law, enforcing the law for the people, making fairness and justice, serving the overall situation, and following the party's leadership", clearly and accurately summarizing the core content, essential requirements, value pursuit, important mission and fundamental guarantee of the socialist rule of law, and reflecting the organic unity of the party's leadership, the people's decisive right in business management as the masters, and the law-based governance. Starting from the overall situation of the socialist modernization drive, adhering to the Marxist jurisprudence theory as a guide, conscientiously summing up the practical experience of China's legal construction and drawing on the achievements of the world's rule of law, we make this important decision, which guide the construction of socialist rule of law and has a long-term guiding significance. Therefore, the socialist legal culture with Chinese characteristics should naturally be guided by this socialist concept of the rule of law, and then a new type of socialist legal culture with Chinese characteristics is cultivated and constructed in a new era.

\section{Linkages with Local Culture: Rooted in the Mother Culture and Realizing Transformation and Transcendence}

The socialist legal culture with Chinese characteristics is resulted from "absorbing the essence and removing the dross" of traditional Chinese culture. It is a legal culture rooted in the mother culture that has achieved modern transformation and transcendence. Some scholars have pointed out: "The cultural personality shown by certain laws is a manifestation of the internal culture of a country. If we ignore the role of the internal factors of a country's culture and adopt simple "bringism" transplantation in the construction of the rule of law, it will directly cause the disorder of the entire cultural system of the country. Therefore, in the construction of China's legal culture, we must pay attention to the traditional Chinese culture." ${ }^{.6}$ The traditional Chinese culture that has been accumulated and inherited over the past several thousand years of history not only embodies the cultural essence of Chinese splendid civilization, but also has a deep dross formed by the influence of feudal ideas. The essence is mainly embodied in the "harmony" culture and the "peopledominated" thought and the concept of "fairness and justice" to maintain the Chinese nation's life and growth in nature as well as effort and progress, while the negative dross mainly refers to the "ruling-by-people" culture that hinders the development of modern society". The socialist legal culture with Chinese characteristics is a product from creative absorption and innovative transformation of traditional culture.

\section{E. The Relationship with the Achievements of World Civilization: An Indispensable and Important Resource in the Cultivation and Formation of a Socialist Legal Culture with Chinese Characteristics}

If serious treatment of traditional Chinese culture is based on the individuality of the development of things, serious treatment of achievements of Western legal civilization is based on the commonality of the development of things. The socialist legal culture with Chinese characteristics should fully absorb all the excellent legal civilization achievements of mankind. Different countries, nations or legal systems in the world have their own characteristics in the mode and experience of rule of law, but there are always human legal civilization achievements consistent with the general legal construction in them, reflecting the universal value of the development of the rule of law. These excellent achievements of human legal civilization accumulated continuously are the common wealth of mankind, and are the driving force and support for the common development and common advancement of mankind. Therefore, we must open our minds to absorb the positive results of these common humanity legal civilizations. In particular, the development of the rule of law in Western developed countries started early and has undergone a relatively long-term development process, which objectively provides us with many useful lessons that we can learn from. Therefore, the achievements of Western legal civilization should be an indispensable and important resource for the cultivation and formation of socialist legal culture with Chinese characteristics.

\section{CONCLUSION}

The study on the connotation of the socialist legal culture with Chinese characteristics is only the foundation and beginning of the entire legal culture construction, and later we should conduct further discussions on the state and path of the legal culture construction, to provide advice and suggestions on the construction of socialist legal culture with Chinese characteristics.

\section{REFERENCES}

[1] Xi Jinping. Speech at the celebration of the 95th anniversary of the founding of the Communist Party of China [N]. People's Daily, 201607-01.

[2] Liu Zuoxiang, Several Theoretical Issues of Legal Culture[J], Law Forum, 2012(1).

[3] Liu Bin/The Category of Research on Contemporary Chinese Legal Culture[J], China University of Political Science and Law, 2009(6)

[4] A Summary of the Symposium on "Traditional Culture and Chinese Rule of Law"[J], China University of Political Science and Law, 2012(4)

[5] [US] Crookhon. Culture and Individuals [M]d. translated by Gao Jia et al., Hangzhou: Zhejiang People's Publishing House, 1986.

[6] Li Yuqing. The Value of Traditional Confucianism on the Construction of Legal Culture[J]. Journal of East China University of Science and Technology(Social Sciences Edition), 2010(3) 